\title{
PENGARUH KONSENTRASI EKSTRAK DAUN CINCAU HIJAU (Cycle barbata L. Miers) DAN SUHU EKSTRAKSI TERHADAP KARAKTERISTIK MIE BASAH
}

\author{
Hapsari Titi Palupi*) \\ *) Staf Pengajar Prodi ITP, Fakultas Pertanian Universitas Yudharta Pasuruan \\ Email: hapsari76@gmail.com
}

\begin{abstract}
Abstrak
Mie merupakan makanan yang banyak dijumpai dan disukai di masyarakat. Untuk memperkaya kandungan gizi mie ditambahkan ekstrak gel daun cincau hijau (Cyclea barbata Miers). Gel cincau hijau memiliki sifat fisik sebagai hidrokoloid dan pembentuk gel yang dapat memberikan sifat pada ketegaran, kekokohan dan elastisitas mie. Tujuan penelitian ini adalah mempelajari pengaruh konsentrasi ekstrak daun cincau hijau dan suhu ekstraksi terhadap karakteristik mie basah. Perlakuan terbaik adalah konsentrasi ekstrak daun cincau hijau 5\% dan suhu ekstraksi 40\% dengan nilai kadar air $39.52 \%$, kadar serat kasar $0.98 \%$, waktu masak 3.00 menit, kapasitas penyerapan air $1.16 \%$, tekstur $1.70 \mathrm{~mm} / \mathrm{g}$ det, kecerahan warna 45.40 dan organoleptik rasa 4.40 (suka), warna 4.10 (suka) tekstur 4.30 (suka) dan aroma 4.00 (suka).
\end{abstract}

Kata Kunci : Ekstrak daun cincau hijau, suhu ekstraksi, mie basah

\begin{abstract}
Noodle is the most available and favorable food in our society. To enrich the content of noodle's nutrition, the extraction of green grass jelly (Cycle barbata L. Miers) leaf is added. Green grass jelly has physical property as hydrocolloids and jelly constructor which can contribute to the characteristics of noodle's rigidity, robustness and elasticity. The objective of this research is to know the effects of concentration of green grass jelly's extraction and extraction temperature on characteristics of wet noodle. The best treatment is concentration of extraction of green grass jelly $5 \%$ and temperature extraction $40 \%$ with water content $39.52 \%$, dietary fiber content $0.98 \%$, time cooking $3.00 \mathrm{~min}$, capacity of water absorption $1.16 \%$, texture $1.70 \mathrm{~mm} / \mathrm{g} \mathrm{sec}$, brightness 45.40 and organoleptic taste 4.40 (like), color 4.10 (like), texture 4.30 (like) and flavor 4.00 (like).
\end{abstract}

Key words : green grass leaf extract, extraction temperature, wet noodle

\section{PENDAHULUAN}

Mie merupakan makanan dan sumber karbohidrat. Protein yang banyak dijumpai dan disukai gluten tepung terigu dapat masyarakat. Mie memiliki memberikan sifat elastisitas dan karakteristik yang berbeda kokoh pada tekstur mie basah yang dipengaruhi oleh jenis bahan baku, dihasilkan. Mie yang berkualitas warna, dan rasa. Mie basah berbahan ditentukan oleh tekstur, warna dan baku utama tepung terigu, memiliki juga dipengaruhi oleh bahan baku kandungan protein tepung (gluten) penyusunnya. Sebagai makanan 
yang banyak digemari dan dikonsumsi, maka diperlukan bahan yang dapat memperkaya kandungan gizinya.

Cincau hijau memiliki fungsi sebagai pewarna hijau alami, sumber antioksidan kaya klorofil dan sumber serat alami. Daun cincau diekstrak menggunakan air, sehingga menghasilkan gel. Gel cincau hijau mengandung polisakarida pektin, bersifat seperti agar-agar. Menurut Nurdin et al. (2005) gel daun cincau mengandung antioksidan dan klorofil. Cincau hijau dapat berfungsi sebagai sumber serat alami dan pewarna alami yang kaya akan klorofil. Pitojo (2008) menyatakan daun cincau hijau (Cycle barbata L. Miers) mampu membentuk jendalan seperti agar-agar. Berdasarkan penelitian Dewi (2010) penambahan agar-agar yang merupakan hidrokoloid, bahan pengental dan pembentuk gel dapat memeberikan sifat pada ketegaran, kekokohan dan elastisitas dari mie kering.

Cincau hijau (Cycle barbata L. Miers) dapat memiliki sifat seperti agar-agar. Dengan latar belakang seperti tersebut di atas, maka diperlukan penelitian mengenai pengaruh ektraksi daun cincau hijau pada konsentrasi dan suhu pengekstrak yang berbeda terhadap karakteristik mie basah. Penelitian ini bertujuan mempelajari pengaruh konsentrasi ekstrak daun cincau hijau (Cycle barbata L. Miers) dan suhu ekstraksi terhadap karakteristik mie basah.

\section{METODOLOGI}

\section{Bahan dan alat}

Bahan baku pembuatan mi adalah daun cincau hijau, tepung terigu, telur, air, garam dan minyak. $\mathrm{H}_{2} \mathrm{SO}_{4}$, larutan $\mathrm{HCl} 0.1 \mathrm{~N}$, larutan $\mathrm{H}_{3} \mathrm{BO} 33 \%$, larutan indikator metil merah dan penolftalein, serta pelarut petroleum eter.

Alat pembuat mi adalah mesin roll/ pengepres, alat pencetak, pisau, baskom, sendok. Alat untuk analisis kimia adalah cawan, oven listrik, timbangan analitik, digestion unit, buret, pipet ukur, bola hisap, beaker glass, erlenmeyer, spatula kaca, dan labu ukur, hot plate, kertas saring, gelas ukur, krus porselen, penjepit cawan, dan kompor listrik, color meter Minolta, dan tensile strength.

\section{Rancangan Penelitian}

Rancangan penelitian yang digunakan adalah Rancangan Acak Kelompok Faktorial yang terdiri dari 2 faktor, yang masing-masing faktor terdiri dari 3 level dan diulang 3 kali. Faktor 1 : Konsentrasi ekstrak daun cincau hijau, terdiri dari 3 level yaitu :

$$
\begin{aligned}
& \text { A1 }=\text { Konsentrasi } 2,5 \%, \\
& \text { A2 }=\text { Konsentrasi } 5 \% \\
& \text { A3 }=\text { Konsentrasi } 7,5 \%
\end{aligned}
$$

Faktor 2 : Suhu ekstraksi, terdiri dari 2 level yaitu

$\mathrm{B} 1=$ suhu ekstraksi $30^{\circ} \mathrm{C}$

$\mathrm{B} 2=$ suhu ekstraksi $40^{\circ} \mathrm{C}$

Terdapat 6 kombinasi perlakuan yang diulang 3 kali.

\section{Tahapan penelitian}

\section{Ektraksi gel daun cincau perdu}

- Pilih daun yang berkualitas bagus dan segar

- Daun cincau hijau dicuci agar terbebas dari kotoran, dengan cara siram dan rendam menggunakan air bersih

- Buang dan dipisahkan daun dari tangkainya

Daun cincau ditimbang dan
ditambahkan air sesuai perlakuan


- Daun diekstrak sesuai dengan perlakuan menggunakan suhu berbeda

- Ekstraksi dilakukan dengan meremas-remas daun didalam air agar tidak menimbulkan buih

- Saring larutan yang masih agak encer dengan kain penyaring

- Biarkan gel cincau encer menjadi kental

\section{Pembuatan Mie}

- Pencampuran bahan baku dan tambahan yaitu tepung terigu, ekstrak gel cincau, telur, garam.

- Pengulenan adonan secara berulang-ulang hingga terasa licin dan elastis di tangan.

. Pembentukan lembaran, dengan meletakkan adonan diantara 2 lembar plastik dan tipiskan setebal $3 \mathrm{~mm}$.

- Pembentukan mie dengan alat pencetak

- Kukus atau rebus mie selama 5 menit

- Mie hasil perebusan, dinginkan dan ditiriskan dan ditambahkan minyak agar terlihat halus dan tidak lengket.

\section{Pengumpulan Data}

Data yang diambil diperoleh dari pengukuran parameter kimia, fisik, dan organoleptik. Parameter kimia yaitu analisa kadar air, kadar serat kasar. Parameter fisik meliputi tekstur, kapasitas penyerapan air, waktu masak dan warna (colorrider Minolta). Parameter organoleptik meliputi kesukaan terhadap bau, rasa, warna dan tekstur.

\section{Analisis Data}

Data yang diperoleh dari hasil analisis fisik dan kimia selanjutnya dianalisis secara statistik menggunakan Rancangan Acak
Kelompok dengan dua faktor. Setelah itu dilanjutkan dengan uji pembeda DMRT dengan selang kepercayaan $5 \%$ atau $1 \%$. Data hasil organoleptik dianalisis dengan metode statistik Uji Friedman.

\section{HASIL DAN PEMBAHASAN}

\section{Kadar air}

Kadar air mie akibat berbagai perlakuan adalah $37.23 \%$ sampai $39.26 \%$. Hasil analisis ragam menunjukkan konsentrasi ekstrak daun cincau perdu yang berbeda dan suhu ekstraksi cincau perdu berpengaruh sangat nyata terhadap kadar air mie basah.

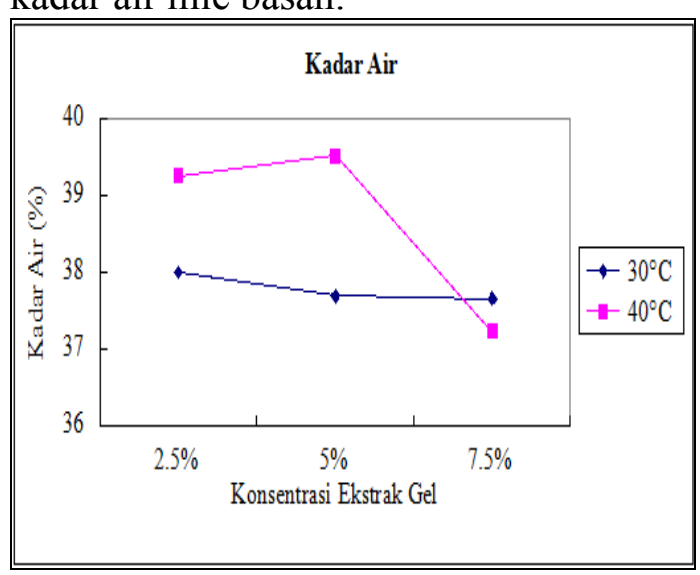

Gambar 1. Konsentrasi ekstrak daun cincau hijau dan suhu ekstraksi terhadap kadar air mie basah.

Perlakuan konsentrasi ekstrak daun cincau perdu $7,5 \%$, dan suhu ekstraksi $40^{\circ} \mathrm{C}$ memberikan kadar air mie basah tertinggi yaitu $39.26 \%$, sedangakan perlakuan konsentrasi ekstrak daun cincau perdu $7,5 \%$, dan suhu ekstraksi $40^{\circ} \mathrm{C}$ memberikan kadar air mie terendah pada nilai $37.23 \%$. Hal ini disebabkan suhu ekstraksi yang lebih tinggi, pada suhu $40^{\circ} \mathrm{C}$, semakin banyak gel terekstrak. Kondisi ini menyebabkan semakin banyak air pada mie basah akan 
terperangkap dan terikat pada membentuk gel sehingga air bebasnya semakin menurun.

Gel daun cincau perdu merupakan koloid hidrofil yang mampu menangkap cairan didalamnya. Gelatin cincau terbentuk karena dispersi pektin ke dalam cairan. Berdasarkan penelitian Wulandari dan Wahono (2015) penggunaan senyawa hidrokoloid pada pembuatan mie kering memiliki kemampuan sebagai pembentukan gel yang berpengaruh pada kadar air mie kering. Struktur gel semakin kokoh maka air yang terperangkap semakin banyak sehingga air yang menguap selama proses pengeringan semakin kecil.

\section{Kadar serat kasar}

Kadar serat mie akibat berbagai perlakuan adalah $0.98 \%$ sampai $1.73 \%$. Hasil analisis ragam menunjukkan konsentrasi ekstrak daun cincau hijau yang berbeda dan suhu ekstraksi daun cincau perdu berpengaruh sangat nyata kadar serat mie basah.

Dari Gambar 2. menunjukkan bahwa perlakuan suhu ekstraksi $40^{\circ} \mathrm{C}$ menghasilkan kadar serat yang cenderung lebih rendah dibandingkan ekstraksi $30^{\circ} \mathrm{C}$. Dari hasil uji beda (Duncan) perlakuan suhu ekstraksi $30^{\circ} \mathrm{C}$ berbeda dengan perlakuan suhu ekstraksi $40^{\circ} \mathrm{C}$. Perlakuan suhu ekstraksi $40^{\circ} \mathrm{C}$ menghasilkan mie yang memiliki kadar serat kasar rendah.

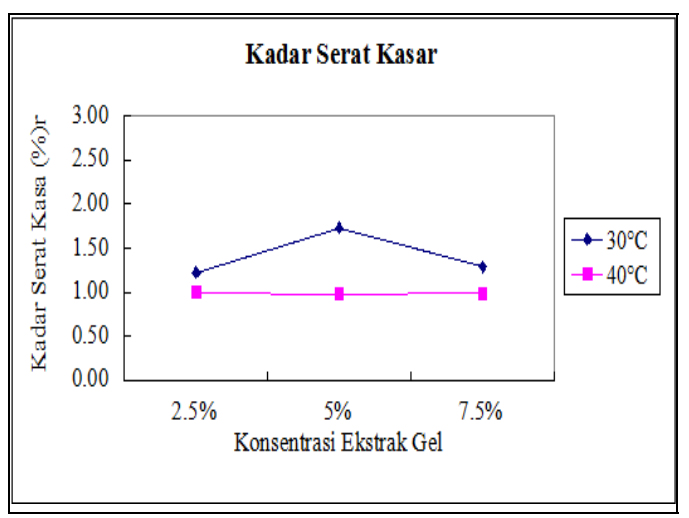

Gambar 2. Konsentrasi ekstrak daun cincau hijau dan suhu ekstraksi terhadap kadar serat mie basah.

Daun cincau hijau mengandung serat kasar yaitu senyawa pektin yang merupakan polisakarida pembentuk gel. Pektin merupakan senyawa hidrokoloid yang terdiri atas senyawa galakturonat yang mengandung gugus metoksil. Suhu ekstraksi mempengaruhi jumlah dan komposisi gel pektin yang terbentuk. Menurut Rahayu dkk. (2013) faktor yang mempengaruhi adalah suhu pengeringan, suhu ini harus tetap di jaga karena jika suhu pengeringan di atas $60^{\circ} \mathrm{C}$ maka pektin akan mengalami kerusakan. Konsentrasi ekstrak daun $5 \%$ pada suhu $30^{\circ} \mathrm{C}$ memberikan kadar serat kasar mie yang besar dan lebih tinggi dibandingkan penambahan konsentrasi ekstrak daun 2,5\%. Jumlah air yang ditambahkan waktu ekstraksi meningkatkan jumlah pektin yang terekstrak.

\section{Waktu masak}

Waktu masak mie pada penelitian ini adalah 2.50 menit sampai 3.00 menit. Hasil analisis ragam menunjukkan konsentrasi ekstrak daun cincau hijau dan suhu ekstraksi daun cincau berpengaruh 
sangat nyata terhadap waktu masak mie basah.

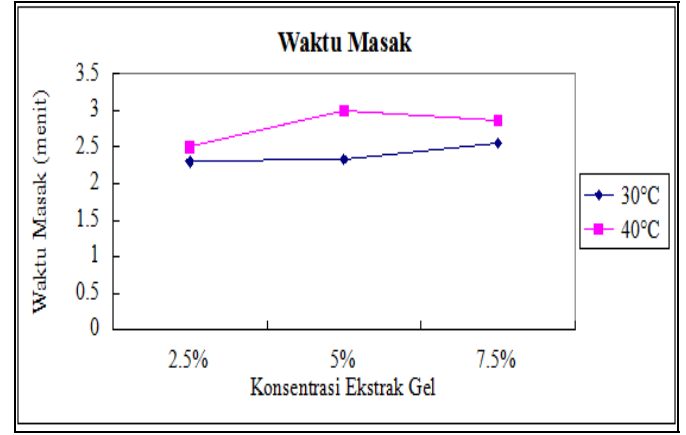

Gambar 3. Konsentrasi ekstrak daun cincau hijau dan suhu ekstraksi terhadap waktu masak mie basah.

Berdasarkan Gambar 3. mie basah dengan perlakuan konsentrasi ekstrak daun cincau hijau 5\% dan suhu ekstraksi $40^{\circ} \mathrm{C}$ memberikan waktu masak mie basah tertinggi yaitu 3 menit, namun tidak berbeda dengan perlakuan konsentrasi ekstrak gel cincau perdu $7,5 \%$ dan suhu air pengekstrak $40^{\circ} \mathrm{C}$. Nampak juga bahwa perlakuan suhu ekstraksi $40^{\circ} \mathrm{C}$ memberikan waktu masak yang lebih lama dibandingkan dengan suhu $30^{\circ} \mathrm{C}$. Hal ini disebabkan semakin tinggi konsentrasi ekstrak daun cincau dan suhu $40^{\circ} \mathrm{C}$ semakin banyak gel terekstak. Gel cincau hijau mengandung senyawa hidrokoloid yang dapat mengikat air dalam jumlah yang banyak pada saat proses pemasakan mie sehingga meningkatkan temperatur pembentukan pasta. Menurut Jarnsuwan, S. and Thongngam M. (2012) penambahan senyawa hidrokoloid dapat merubah sifat pembentukan pasta, karena terbentuk ikatan antara senyawa hidrokoloid dan gugus hidroksil dari pati., sehingga akan meningkatkan temperatur pembentukan pasta.

\section{Kapasitas penyerapan air}

Kapasitas pengikatan air mie basah pada penelitian ini adalah $0.98 \%$ sampai $1.73 \%$. Hasil analisis ragam menunjukkan konsentrasi ekstrak daun cincau hiijau yang berbeda dan suhu ekstraksi gel cincau hijau berpengaruh sangat nyata terhadap ka.pasitas penyerapan air.

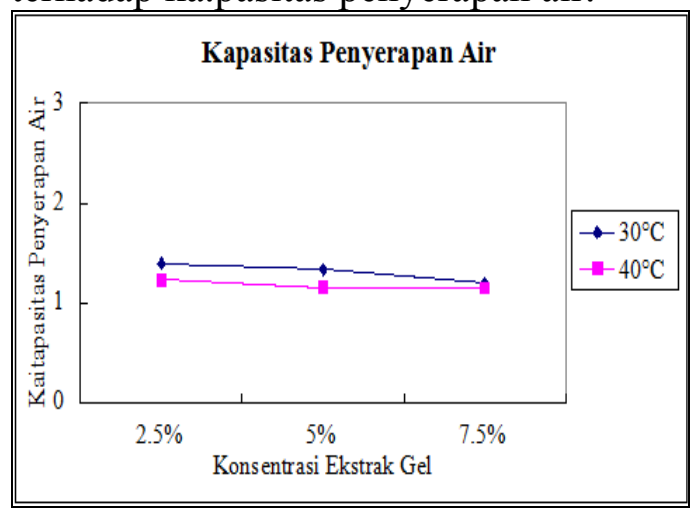

Gambar 4. Konsentrasi ekstrak daun cincau hijau dan suhu ekstraksi terhadap kapasitas penyerapan air mie basah.

Konsentrasi ekstrak gel cincau hijau 2,5\%, dan suhu ekstraksi $30^{\circ} \mathrm{C}$ memberikan kapasitas penyerapan air mie basah tertinggi yaitu 1,73\%. Dari Gambar 4 dan uji beda Duncan menunjukkan terdapat perbedaan kapasitas penyerapan air pada mie dipengaruhi oleh suhu air pengekstrak gel cincau. Penambahan senyawa hidrokoloid gel cincau pada pembuatan mie akan memberi pengaruh pada kapasitas penyerapan air mie. Menurut Jarnsuwan, S. and Thongngam M. (2012) penggunaan senyawa hidrokoloid akan mempengaruhi sifat pasta dari mie sehinga dapat memperbaiki kualitas yang dihasilkan.

\section{Tekstur}

Tekstur mie basah pada karena perlakuan konsentrasi ekstrak daun cincau hijau dan suhu air pengekstrak yang berbeda adalah $1.65 \mathrm{~mm} / \mathrm{g} \mathrm{dt}$ sampai $2.70 \mathrm{~mm} / \mathrm{g}$ dt. Hasil analisis 
ragam menunjukkan konsentrasi ekstrak daun cincau hijau yang berbeda dan suhu ekstraksi gel berpengaruh sangat nyata terhadap tekstur mie basah.

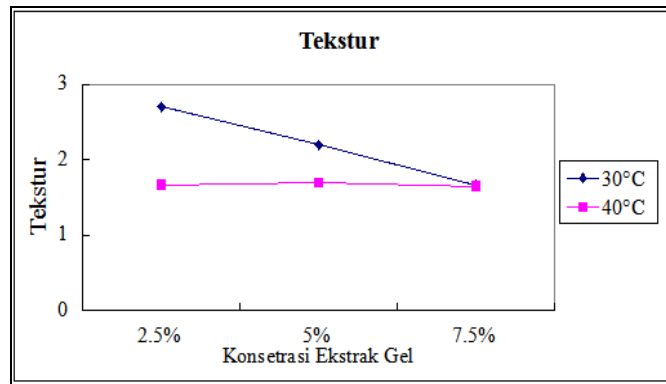

Gambar 5. Pengaruh konsentrasi ekstrak daun cincau hijau dan suhu ekstraksi terhadap tekstur mie basah

Berdasarkan Gambar 5 . konsentrasi ekstrak daun cincau 7.5\%, dan suhu ekstraksi $40^{\circ} \mathrm{C}$ memberikan tekstur mie basah terendah yaitu 1.65 $\mathrm{mm} / \mathrm{g}$ dt. Perlakuan konsentrasi ekstrak gel cincau hijau 2,5\%,5\%, $7,5 \%$ pada suhu ekstraksi $40^{\circ} \mathrm{C}$ tidak memberikan perbedaan terhadap tekstur mie. Suhu air yang berbeda memberikan perbedaan yang nyata terhadap tekstur mie. Gelatin cincau perdu memiliki sifat yaitu berbentuk jendalan seperti agar-agar, merupakan sistem koloid hidrofil yang berpengaruh terhadap tekstur (Pitojo 2008) Penambahan hidrokoloid yang semakin tinggi akan meningkatkan kekompakan matrik gel dan mengurangi struktur berongga yang menyebabkan menurunkan kekenyalan .

\section{Warna (kecerahan)}

Pengukuran warna menggunakan Chromameter Minolta memberikam skala $\mathrm{L}^{*}$ mengukur nilai kecerahan antara hitam sampai putih, koordinat nilai $\mathrm{L}=0$ sampai $\mathrm{L}=100$. Warna (kecerahan) mie basah pada karena perlakuan konsentrasi ekstrak daun cincau hijau dan suhu air pengekstrak yang berbeda adalah +40.22 sampai $50.80 \%$.

Hasil analisis ragam menunjukkan konsentrasi ekstrak daun cincau perdu yang berbeda dan suhu ekstraksi daun cincau hijau berpengaruh sangat nyata dengan uji Duncan $(\alpha=0,01)$ terhadap kecerahan warna mie basah.

Berdasarkan Gambar 6 semakin tinggi konsentrasi gel dan suhu ekstraksi yang semakin meningkat maka tingkat kecerahan mie semakin menurun. Gambar tersebut memperlihatkan bahwa mie basah dengan perlakuan konsentrasi ekstrak gel cincau perdu 2,5\%, dan suhu ekstraksi $30^{\circ} \mathrm{C}$ memberikan tingkat kecerahan mie basah tertinggi yaitu 39.26\%, sedangakan perlakuan konsentrasi ekstrak gel cincau perdu 7,5\%, dan suhu ekstraksi $40^{\circ} \mathrm{C}$ memberikan kadar air mie terendah pada nilai $37.23 \%$. Hal ini disebabkan semakin tinggi konsentrasi ekstrak gel cincau dan suhu $40^{\circ} \mathrm{C}$ semakin banyak gel terekstak. Apabila ditambahkan pada mie basah menyebabkan kandungan gel cincau yang terekstrak semakin tinggi.

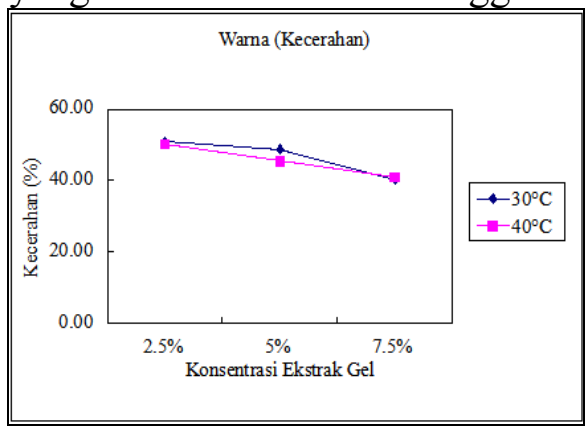

Gambar 6. Pengaruh konsentrasi ekstrak gel cincau hijau dan suhu ekstraksi terhadap warna (kecerahan) mie basah

Cincau hijau mengandung pigmen klorofil yang memberikan warna hijau, sehingga mie basah yang dihasilkan cenderung berwarna hijau. 
Menurut Rahayu dkk. (2013) gel cincau rambat memiliki warna keruh hijau licin karena kandungan klorofil pada daunnya.

\section{Organoleptik warna}

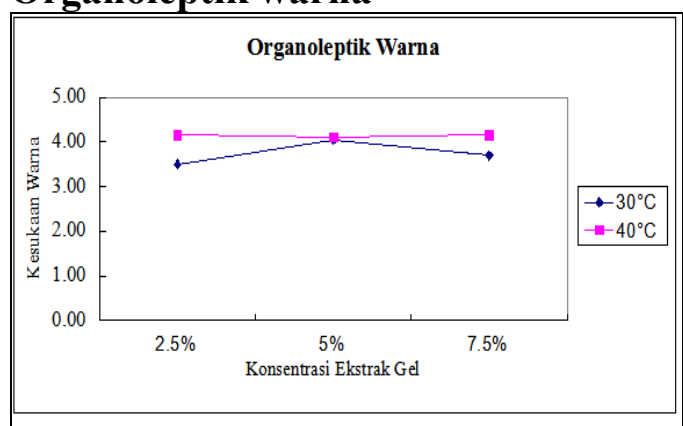

Gambar 7. Pengaruh konsentrasi ekstrak daun cincau hijau dan suhu ekstraksi gterhadap organoleptik warna mie basah

Hasil analisis ragam menunjukkan konsentrasi ekstrak daun cincau hijau dan suhu ekstraksi yang berbeda berpengaruh sangat nyata $(\alpha=0,01)$ terhadap organoleptik warna mie basah. Mie basah pada penelitian ini mempunyai kesukaan warna antara 3.5 (netral) sampai 4.150 (suka).

Mie basah dengan perlakuan secara organoleptik mempunyai kesukaan terhadap warna yang terkecil adalah perlakuan yaitu konsentrasi ekstrak gel cincau 2,5\%, suhu air pengekstrak $30^{\circ} \mathrm{C}$. Sedangkan perlakuan konsentrasi ekstrak gel cincau 7,5\%, suhu air pengekstrak $40^{\circ} \mathrm{C}$ memiliki tingkat kesukaan tertinggi. Berdasarkan pengukuran sifat fisik warna menggunakan Chromameter Minolta perlakuan tersebut menghasilkan warna mie yang lebih hijau, karena kandungan klorofil pada gel hasil ekstraksi daun cincau hijau.

\section{Organoleptik tekstur}

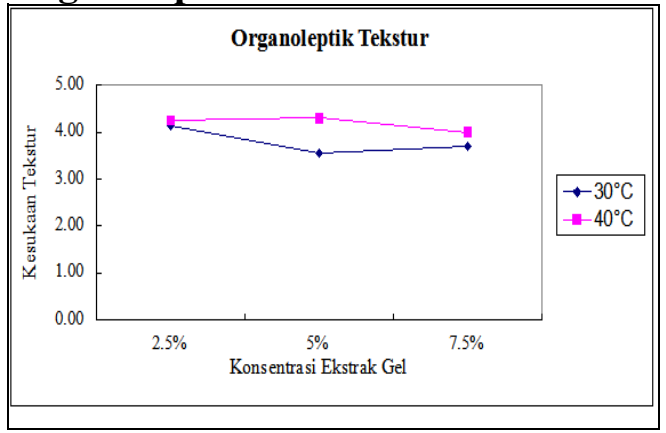

Gambar 8. Pengaruh konsentrasi ekstrak daun cincau hijau dan suhu ekstraksi gel terhadap organoleptik tekstur mie basah

$$
\text { Hasil analisis ragam }
$$
menunjukkan konsentrasi ekstrak daun cincau hijau dan suhu ekstraksi berpengaruh nyata terhadap organoleptik tekstur mie basah. Mie basah pada penelitian ini mempunyai kesukaan tekstur antara 3.55 (netral) sampai 4.150 (suka). Kesukaan terhadap tekstur mie tertinggi pada perlakuan konsentrasi ekstrak gel cincau hijau $25 \%$ dan suhu ekstraksi $40^{\circ} \mathrm{C}$. Mie basah dengan perlakuan suhu ekstraksi $\quad 40^{\circ} \mathrm{C}$ tingkat mempunyai kesukaan terhadap tekstur mie yang tertinggi dan berbeda nyata dari suhu ekstraksi $30^{\circ} \mathrm{C}$.

\section{Organoleptik rasa}

Hasil analisis ragam menunjukkan konsentrasi ekstrak daun cincau hijau dan suhu ekstraksi gel yang berbeda berpengaruh nyata dengan terhadap organoleptik rasa mie basah. Mie basah pada penelitian ini mempunyai kesukaan rasa antara 3,85 (netral) sampai 4,65 (suka). 


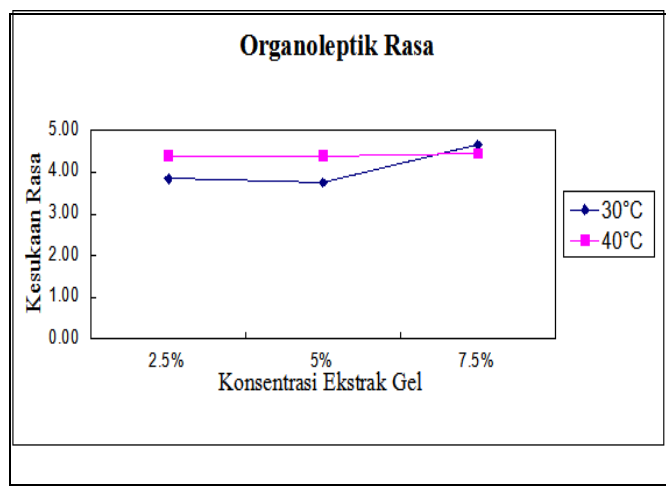

Gambar 9. Pengaruh konsentrasi ekstrak daun cincau hijau dan suhu ekstraksi terhadap organoleptik rasa mie basah

Gambar 9 menunjukkan perlakuan suhu ekstraksi $40^{\circ} \mathrm{C}$ memberikan nilai kesukaan lebih tinggi dari pada suhu ekstraksi $30^{\circ} \mathrm{C}$. Perlakuan suhu ekstrasi $40^{\circ} \mathrm{C}$, menyebabkan semakin banyak gel terekstrak. Sehingga jika ditambahkan pada mie basah menyebabkan kandungan gel cincau yang terekstrak semakin tinggi. I

\section{Organoleptik aroma}

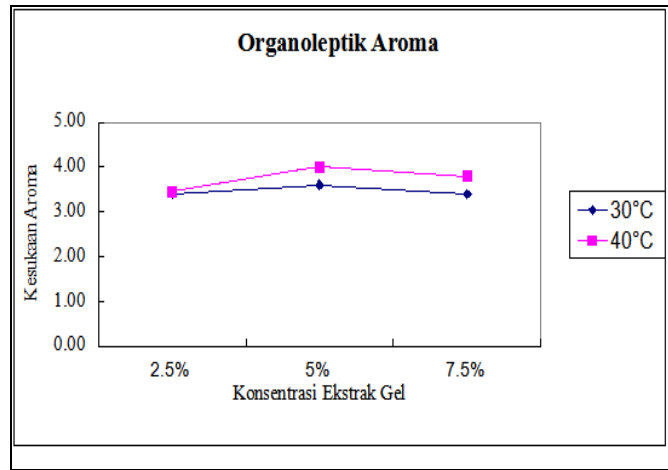

Gambar 10. Pengaruh konsentrasi ekstrak daun cincau hijau dan suhu ekstraksi terhadap aroma mie basah

\section{Hasil analisis ragam} menunjukkan konsentrasi ekstrak daun cincau hijau yang berbeda dan suhu ekstraksi gel yang berbeda tidak berpengaruh nyata dengan terhadap organoleptik aroma mie basah. Mie basah pada penelitian ini mempunyai kesukaan terhadap aroma antara 2.8 (netral) sampai 4.15 (suka).

\section{KESIMPULAN}

1. Perlakuan konsentrasi ekstrak daun cincau hijau dan suhu ekstraksi berpengaruh nyata terhadap kadar air, kadar serat kasar, waktu masak, kapasitas penyerapan air, tekstur, kecerahan warna dan organoleptik rasa, warna dan tekstur. Serta tidak berpengaruh nyata pada organoleptik aroma.

2. Perlakuan terbaik adalah konsentrasi ekstrak gel cincau hijau $5 \%$ dan suhu ekstraksi 40\% dengan nilai kadar air $39.52 \%$, kadar serat kasar $0.98 \%$, waktu masak 3.00 menit, kapasitas penyerapan air $1.16 \%$, tekstur $1.70 \mathrm{~mm} / \mathrm{g}$ dt, kecerahan warna $45.40 \%$ dan organoleptik rasa 4.40 (suka), warna 4.10 (suka) tekstur.4.30 (suka) dan aroma 4.00 (suka).

\section{DAFTAR PUSTAKA}

Astawan, Made. 2006. Membuat Mi \& Bihun. Niaga Swadaya

Dewi, Eko Nurcahya. 2010. Quality Evaluation of Dried Noodle With Seaweeds Pure Subtitution. Journal of Coastal Development ISSN : 1410-5217 Volume 14, Number 2, February 2011 : 151-158

Pitojo, Setijo. 2008. Khasiat Cincau Perdu. Penerbit Kanisius. Yogyakarta.

Nurdin, S.U., A. S. Zuidar \& Suharyono. 2005. Dried Extract From Green Cincau Leaves As Potential Fibre Sources For Food Enrichment. African Crop 
Science Conference Proceedings, Vol. 7. p. 655-658.

Jarnsuwan, S. dan Thongngam M. 2012. Effects of Hydrocolloids on Microstructure and Textural Characteristic of Instant Noodles. Asian Journal of Food and Agro-Industry 5(06): 485-492

Rahayu, Rista., Etna Mayasari Taslim, Sumarno.2013 Pembuatan Serbuk Daun Cincau Hijau Rambat Cyclea Barabat L.Miers Menggunakan Proses maserasi dan Foam mat Drying. Jurnal Teknologi Kimia dan Industri Vol. 2, No. 4.
Widyaningtyas, Mita dan Susanto, Wahono Hadi. 2015. Pengaruh Jenis dan Konsentrasi Hidrokoloid (Carboxy Methyl Cellulose Xanthan Gum dan Karagenan) Terhadap Karaktersitik Mie Kering Berbasis Pasta Ubi jalar Varietas Ase Kuning Jurnal Pangan dan Agroindustri Vol. 3 No 2 p.417-423. 